\section{GREEN INTERMODAL FREIGHT TRANSPORT - GIFT}

The main aim of the GIFT (Green Intermodal Freight Transport) project was to map, analyze and evaluate the status of the transport sector in the GIFT network and propose new policies and strategies in infrastructure, processes, assets, ICT, legislation, norms and harmonization/standardization issues, in order to promote innovative green intermodal freight transport corridors. Pan-European corridors IV, V and VII were selected, since they connect ports to landlocked countries via road and rail infrastructure, have very significant flow of freight from/to Europe and involve important areas such as the Adriatic, the Danube, the Black Sea regions and the Balkans. They have the potential to become green, since the instruments (both economical and operational) that can enhance a better integration of different modes of transport exist. The GIFT network is in great need to enhance its freight transport performance, in order to accelerate economic growth, especially in view of the European debt crisis which is in part due to globalization. In order to be a player at global market, the region needs to enhance its connectivity, especially with the emerging countries. The GIFT project proved multimodal transport is an essential factor.

The structure of the GIFT partnership and the work plan ensured involvement of all key relevant stakeholders and target groups from Bulgaria, Croatia, Greece, Hungary, Italy, Romania, Serbia, Slovakia and Slovenia. Target groups included port authorities, freight forwarders, logistics \& transportation businesses \& associations, chambers of commerce and industrial associations, SMEs and large companies, railway associations, operators of combined transport, operators of rail or road transport, operators of intermodal terminals and operators of inland waterways transport. Stakeholders included the main policy makers (i.e. Ministries of Transport), as well as key transportation operators (i.e. Luka Koper, TRAINOSE, Slovenian Railways, Baja Public Port, Rail Cargo Hungaria, etc.). Faculty of Transport and Traffic Sciences as Croatian partner was activity leader and published deliverable Green Intermodal Freight Transport Cluster Operation Methodology.

Road freight transport is the dominant mode of goods movement across the EU (with a share of 49\%) as it represents a cost effective and flexible mode. Its dominance in SEE countries may also be attributed to the lower requirements for infrastructure, standards, and legal framework. However, road transport exhibits significant weaknesses contributing to considerable CO2 emissions, accidents, increased noise level, road congestion and wear. It is evident that in order to relieve the pressure on the roads, transport modes have to be combined so as to reduce congestion, environmental impact, improve safety, reduce economic impact (due to fatalities and environmental harm), while at the same time meeting modern demands for reliability, speed and safety. The strengthening of intermodality through green transport corridors may be an effective approach to environmentally friendly and safer freight transport. Furthermore, the moderniza-

Table: Green Observatory potential users \& their motivation

\begin{tabular}{|c|c|}
\hline Stakeholder & Motivation to calculate CO2 emissions \\
\hline Shipper with own fleet & $\begin{array}{l}\text { - Green brands / boost corporate image } \\
\text { - Ecological motives } \\
\text { - Economic motives (generating revenue) } \\
\text { - Monitoring issues (Green KPIs) } \\
\text { - Legal and regulatory pressures }\end{array}$ \\
\hline $\begin{array}{l}\text { Freight forwarder/ } \\
\text { Shipper without owned fleet }\end{array}$ & $\begin{array}{l}\text { - Ecological motives } \\
\text { - Marketing tool } \\
\text { - Legal and regulatory pressures } \\
\text { - Monitoring issues (Green KPIs) }\end{array}$ \\
\hline $3 P L$ & $\begin{array}{l}\text { - Ecological motives } \\
\text { - Marketing tool } \\
\text { - Legal and regulatory pressures } \\
\text { - Monitoring issues (Green KPIs) }\end{array}$ \\
\hline Freight carrier & $\begin{array}{l}\text { - Economic motives (minimize transport cost) } \\
\text { - Ecological motives } \\
\text { - Marketing tool } \\
\text { - Legal and regulatory pressure } \\
\text { - Monitoring issues (Green KPIs) }\end{array}$ \\
\hline Government & $\begin{array}{l}\text { - Enforcing transportation policies and programs } \\
\text { - Legislate }\end{array}$ \\
\hline NGOs & $\begin{array}{l}\text { - Monitoring GHG emissions } \\
\text { - Informing governments and public }\end{array}$ \\
\hline
\end{tabular}


tion of administrative processes accompanied with suitable initiatives could lead to substantial increase of the share and efficiency of alternative modes.

Concerning the Danube area (Corridor VII), the river basin has much potential for sustainable and green inland navigation, if the physical capacity of the Danube is improved and existing bottlenecks removed, to ensure the proper level of navigability and the connection of ports tot landlocked countries. These improvements should fully respect the environmental legislation. As far as the Adriatic (Corridor $\mathrm{V}$ ) and Balkan regions (Corridor IV) are concerned, road, sea and rail connections from Italy, Albania and Greece to Danube are often inefficient or simply missing, especially cross-border connections due to past rivalries. Other bottlenecks are the inherent constraints imposed by the political fragmentation and the market-public sector tension.

One of the outputs is GIFT Green Freight Transport Observatory, a web-based tool (www.greenobservatory.eu) for calculation and certification of $\mathrm{CO} 2$ emissions in freight transport operations. The main char- acteristics of the Green Observatory are summarized as follows:

- The calculation of $\mathrm{CO} 2$ emissions is based on European Corridors (PECs IV, V, and VII), business sectors (i.e. shippers, carriers, forwarders, 3PLs) and company level.

- All transit stakeholders, like road, rail, IWW carriers, forwarders, 3PLs, can use this platform. In addition governmental agencies and NGO organizations benefit from system's reports and statistics. Green Observatory does not handle operations from sea carriers.

- The functionalities of the platform focus solely on forms and reports for monitoring and certifying $\mathrm{CO}_{2}$ emissions.

GIFT project is co-funded by the EUROPEAN UNION South East Europe (SEE)-Transnational Cooperation Programme

Prof. Zvonko Kavran, Ph.D.

FPZ GIFT Project Manager

Faculty of Transport and Traffic Sciences University of Zagreb 